\title{
Faster Access to New Knowledge through Continuous Publication
}

The digital revolution has changed society in many areas. Hardly anyone writes oldfashioned letters any more, except perhaps the annual Christmas letter. One reason is that email is much faster and cheaper. Official letters on paper are also almost a thing of the past - if we don't count the ones that are considered so important that they, strangely, are still printed on paper and posted to actual mail boxes.

Newspapers are falling prey to the same trend: digital solutions replace paper editions, giving us fresh news at virtually the same time a story breaks. And we see this trend in the realm of academic publications as well, where most journals now have their own online editions. More and more journals have also been moving the digital revolution another step forward by adopting the principles of Open Access, where articles are published online, freely available for all readers, and subscriptionbased funding is replaced by publication fees.

Arctic Review on Law and Politics went over to Open Access publishing in January 2015. It has been a resounding success for the journal, which has enjoyed a dramatically increased readership compared to the time when the main publishing form was paper. Increased availability and broader distribution have also resulted in more incoming manuscripts, which in turn gives the journal an opportunity for stricter evaluation and thus publishing articles with higher quality.

Now it is time to take the consequences of the digital revolution an additional step further. Until today, the journal maintained the tradition of publishing two issues per year, a natural structure when it was printed on paper and delivered to subscribers by mail. By publishing online and Open Access, however, there is no particular reason to continue this tradition. From January 2017, two years after Arctic Review on Law and Politics went Open Access, we celebrate the consequences of the digital revolution by henceforth publishing articles as soon as they have been through the peer-review process and approved by the editors; in other words, continuous publishing.

Continuous publishing will benefit both our authors and our readers. Authors will have their articles published without unnecessary delay, while readers will gain faster access to new knowledge and the latest research on the High North and neighbouring areas, which Arctic Review on Law and Politics aims to convey. In this way the journal will be even more important and relevant for researchers, academics, NGOs and policy makers. 
The honor of launching continuous publishing goes to Elana Wilson Rowe, senior Research Fellow at the Norwegian Institute of International Affairs (NUPI). In her article Promises, Promises: The Unbuilt Petroleum Environment in Murmansk, she picks up on the idea of the Arctic as a booming oil and gas province, geopolitically and regionally, and discusses the consequences of anticipated or pursued but ultimately unrealized natural resource-based projects. Particularly, she focuses on the Shtokman gas project and illustrates a variety of ways in which the project retained significance in Murmansk, even three years after it was suspended.

An editor of a peer-reviewed journal must be careful about announcing articles that are not fully reviewed and approved. However, I can reveal that in 2017 we will publish a thematic series of articles on consultations between contractors, governments and indigenous peoples in a Canadian-Nordic perspective with professor Hans-Kristian Hernes as guest editor. I welcome readers who have written or are planning to write on this topic to submit manuscripts for consideration and possible inclusion in this upcoming thematic series.

With this I wish returning and new readers of Arctic Review of Law and Politics a Happy New Year with plenty of good academic reading!!

Øyvind Ravna

Editor-in-chief 